\title{
Is intra-articular magnesium effective for postoperative analgesia in arthroscopic shoulder surgery?
}

\author{
Tuba Berra Saritas MD ${ }^{1}$, Hale Borazan MD¹, Selmin Okesli MD¹, Mustafa Yel MD², Seref Otelcioglu MD ${ }^{1}$
}

\begin{abstract}
TB Saritas, H Borazan, S Okesli, M Yel, S Otelcioglu. Is intraarticular magnesium effective for postoperative analgesia in arthroscopic shoulder surgery? Pain Res Manag 2015;20(1):35-38.
\end{abstract}

BACKGROUND: Various medications are used intra-articularly for postoperative pain reduction after arthroscopic shoulder surgery. Magnesium, a $\mathrm{N}$-methyl-D-aspartate receptor antagonist, may be effective for reduction of both postoperative pain scores and analgesic requirements.

METHODS: A total of 67 patients undergoing arthroscopic shoulder surgery were divided randomly into two groups to receive intra-articular injections of either $10 \mathrm{~mL}$ magnesium sulphate $(100 \mathrm{mg} / \mathrm{mL}$; group $\mathrm{M}, \mathrm{n}=34)$ or $10 \mathrm{~mL}$ of normal saline (group $\mathrm{C}, \mathrm{n}=33$ ). The analgesic effect was estimated using a visual analogue scale $1 \mathrm{~h}, 2 \mathrm{~h}, 6 \mathrm{~h}, 8 \mathrm{~h}, 12 \mathrm{~h}, 18 \mathrm{~h}$ and $24 \mathrm{~h}$ after operation. Postoperative analgesia was maintained by intra-articular morphine $(0.01 \%, 10 \mathrm{mg})+$ bupivacaine $(0.5 \%, 100 \mathrm{~mL})$ patientcontrolled analgesia device as a $1 \mathrm{~mL}$ infusion with a $1 \mathrm{~mL}$ bolus dose and 15 min lock-out time; for visual analogue scale scores $>5$, intramuscular diclofenac sodium $75 \mathrm{mg}$ was administered as needed during the study period (maximum two times).

RESULTS: Intra-articular magnesium resulted in a significant reduction in pain scores in group $\mathrm{M}$ compared with group $\mathrm{C} 1 \mathrm{~h}, 2 \mathrm{~h}, 6 \mathrm{~h}, 8 \mathrm{~h}$ and $12 \mathrm{~h}$ after the end of surgery, respectively, at rest and with passive motion. Total diclofenac consumption and intra-articular morphine + bupivacaine consumption were significantly lower in group M. Postoperative serum magnesium levels were significantly higher in group $\mathrm{M}$, but were within the normal range.

CONCLUSIONS: Magnesium causes a reduction in postoperative pain in comparison to saline when administered intra-articularly after arthroscopic shoulder surgery, and has no serious side effects.

Key Words: Bupivacaine; Intra-articular; Magnesium; Morphine; Patientcontrolled analgesia

A rthroscopic surgery is frequently performed in outpatient settings. Postoperative pain is an important outcome of surgery that can result in late discharge to home and limit early rehabilitation. Opioids, nonsteroidal anti-inflammatory drugs, clonidine, neostigmine and magnesium sulphate have been injected intra-articularly, with variable effects (1-4).

Magnesium is the fourth most common cation in the body. It has important physiological roles in enzymatic activation of energy metabolism and protein synthesis (5). Magnesium has also been shown to have antinociceptive effects in animal and human models of chronic pain $(6,7)$. The analgesic properties of magnesium are primarily related to antagonism of the $N$-methyl-D-aspartate (NMDA) receptor and the regulation of calcium influx into cells $(6,8,9)$. This analgesic effect was first demonstrated in humans in 1996, when magnesium was administered intravenously in the perioperative period (7). It has been reported to reduce postoperative analgesic requirements $(10,11)$.

The analgesic efficacy of intra-articular magnesium after knee surgery has been demonstrated; however, its effect after shoulder surgery has not

\author{
Le magnésium intra-articulaire est-il une analgésie \\ efficace après une arthroscopie de l'épaule?
}

HISTORIQUE : Plusieurs médicaments sont administrés par voie intraarticulaire pour soulager la douleur après une arthroscopie de l'épaule. Le magnésium, un antagoniste des récepteurs du $\mathrm{N}$-méthyl-D-aspartate, est peut-être efficace pour réduire les indices de douleur postopératoire et les besoins analgésiques.

MÉTHODOLOGIE : Au total, 67 patients ayant subi une arthroscopie de l'épaule ont été divisés au hasard en deux groupes pour recevoir des injections intra-articulaires de $10 \mathrm{~mL}$ de sulfate de magnésium $(100 \mathrm{mg} / \mathrm{mL}$; groupe $\mathrm{M}, \mathrm{n}=34$ ) ou de $10 \mathrm{~mL}$ de soluté physiologique normal (groupe $\mathrm{C}$, $\mathrm{n}=33$ ). L'effet analgésique était évalué au moyen d'une échelle analogique visuelle une, deux, six, huit, 12,18 et 24 heures après l'opération. L'analgésie postopératoire était maintenue au moyen de morphine $(0,01 \%$, $10 \mathrm{mg})+$ bupivacaïne $(0,5 \%, 100 \mathrm{~mL})$ intra-articulaire administrée par un dispositif d'analgésie contrôlé par le patient sous forme d'infusion de $1 \mathrm{~mL}$ à la dose de bolus de $1 \mathrm{~mL}$, suivie de 15 minutes de blocage. Lorsque les indices de l'échelle analogique visuelle étaient supérieurs à $5,75 \mathrm{mg}$ de diclofénac sodique par voie intraveineuse étaient administrés au besoin pendant la période de l'étude (maximum de deux infusions).

RÉSULTATS : Le magnésium intra-articulaire a suscité une réduction significative des indices de douleur dans le groupe $\mathrm{M}$ par rapport au groupe $\mathrm{C}$ une, deux, six, huit et 12 heures après la fin de l'opération, respectivement, au repos et lors de mouvements passifs. La consommation totale de diclofénac et de morphine + bupivacaïne intra-articulaire était considérablement plus faible dans le groupe M. Les taux postopératoires de magnésium sérique étaient beaucoup plus élevés dans le groupe $M$, mais demeuraient dans une plage normale.

CONCLUSIONS : Par rapport au soluté physiologique, le magnésium cause une diminution de la douleur postopératoire lorsqu'il est administré par voie intra-articulaire après une arthroscopie de l'épaule, et il ne cause pas de graves réactions indésirables.

been reported in the literature (4). Accordingly, the aim of the present study was to evaluate the potential analgesic effect of magnesium when injected intra-articularly during arthroscopic shoulder surgery.

\section{METHODS}

With the approval of the local ethics committee (2009-249) and signed informed patient consent, 67 patients (38 men and 29 women) who were between 18 and 65 years of age, with American Society of Anesthesiologists physical status class I to II, who were scheduled to undergo arthroscopic rotator cuff repair and were able to use a patientcontrolled analgesia device (Pain Management Provider; Abbott Laboratories, USA) were included in the present study. Exclusion criteria were: known allergies to one of the study drugs; major hepatic, renal or cardiovascular dysfunction, especially atrioventricular block; and previous treatment with opioids and calcium channel blockers. The Clinical Trial Registration number is ACTRN12613001360707.

All patients were informed about pain evaluation using a visual analogue scale (VAS) before surgery. The 67 patients were randomly assigned

${ }^{1}$ Anesthesiology and Reanimation Department; ${ }^{2}$ Orthopaedics Department, Necmettin Erbakan U Meram Medical School, Konya, Turkey

Correspondence: Dr Tuba Berra Saritas, Necmettin Erbakan U Meram Medical School, Anesthesiology and Reanimation Department, Konya,

Turkey. Telephone 90-544-366-4244, fax 90-332-223-6181, e-mail tsaritas@konya.edu.tr 
TABLE 1

Demographic features of patients in the control and
magnesium groups

\begin{tabular}{lcc}
\hline & \multicolumn{2}{c}{ Group } \\
\cline { 2 - 3 } & Control $(\mathbf{n}=\mathbf{3 0})$ & Magnesium $(\mathbf{n}=\mathbf{3 0})$ \\
\hline Age, years & $41.6 \pm 10.4$ & $39.8 \pm 9.2$ \\
Body weight, $\mathrm{kg}$ & $76.3 \pm 12.4$ & $77.2 \pm 11.3$ \\
Male/female, $\mathrm{n} / \mathrm{n}$ & $14 / 16$ & $17 / 13$ \\
Operation time, $\min$ & $72.86 \pm 12$ & $74.6 \pm 11.3$ \\
ASA I/ll, $\mathrm{n} / \mathrm{n}$ & $19 / 11$ & $13 / 17$ \\
\hline
\end{tabular}

Data presented as mean $\pm S D$ unless otherwise indicated. ASA American Society of Anesthesiologists

to one of two groups using sealed opaque envelopes containing one of the two treatment regimens. When patients arrived at the operating room, they chose one of the envelopes and a nurse who was not involved in the present study opened the envelope and prepared the study drug. In the magnesium group (group $\mathrm{M})$, patients $(\mathrm{n}=30)$ received $1000 \mathrm{mg}$ magnesium sulphate $(100 \mathrm{mg} / \mathrm{mL})$ intra-articularly in $10 \mathrm{~mL}$ saline. Patients in the control group (group $\mathrm{C} ; \mathrm{n}=30$ ) received $10 \mathrm{~mL}$ saline only.

All patients were premedicated with $0.01 \mathrm{mg} / \mathrm{kg}$ intravenous midazolam. After routine monitoring of patients' heart rate, blood pressure (measured noninvasively) and peripheral oxygen saturation, an infusion of $0.9 \% \mathrm{NaCl}(5 \mathrm{mg} / \mathrm{kg} / \mathrm{h}$ to $7 \mathrm{mg} / \mathrm{kg} / \mathrm{h})$ was initiated. All patients were anesthetized using standard protocols with $2 \mathrm{mg} / \mathrm{kg}$ to $3 \mathrm{mg} / \mathrm{kg}$ propofol, $1 \mu \mathrm{g} / \mathrm{kg}$ to $2 \mu \mathrm{g} / \mathrm{kg}$ fentanyl and $0.5 \mathrm{mg} / \mathrm{kg}$ atracurium. Endotracheal intubation was performed when sufficient muscle relaxation was achieved. During the maintenance of anesthesia, $1 \%$ to $2 \%$ sevoflurane in $40 \% \mathrm{O}_{2}$ and $60 \% \mathrm{~N}_{2} \mathrm{O}$ was administered; no supplemental opioids were given during surgery.

All surgical procedures and intra-articular injections were performed by the same surgeon. The same main arthroscopic portal was used for injection and catheter placement at the end of the surgery before extubation of the patient. The catheter was tunnelled $4 \mathrm{~cm}$ to $5 \mathrm{~cm}$ subcutaneously. Surgical drains were not used in any of the patients. Both the orthopedic surgeon and the attending anesthesiologist were blinded to the drug assignment. The patients were also blinded to the study drug.

Another investigator, who was also blinded to the study drug, performed and recorded measurements at rest and during passive movement of the $\operatorname{arm} 30^{\circ}$ perpendicular anteroposteriorly. Active movement was not evaluated after surgery because it was not permitted by the surgeon during the first $24 \mathrm{~h}$ postoperatively. Analgesia was evaluated using a 10-point linear VAS at $1 \mathrm{~h}, 2 \mathrm{~h}, 6 \mathrm{~h}, 8 \mathrm{~h}, 12 \mathrm{~h}, 18 \mathrm{~h}$ and $24 \mathrm{~h}$ after the operation. VAS was evaluated using a 10-point linear rulerlike device. A score of 0 was defined as no pain and a score of 10 as the worst imaginable pain. At the end of the first postoperative hour, intravenous blood sampling was performed to determine serum magnesium levels.

Postoperative analgesia was maintained by intra-articular morphine $(0.01 \% ; 10 \mathrm{mg})+$ bupivacaine $(0.5 \% ; 100 \mathrm{~mL})$ patientcontrolled analgesia as a $1 \mathrm{~mL}$ infusion with a $1 \mathrm{~mL}$ bolus dose and 15 min lock-out time; additionally, for VAS scores $>5$, intramuscular diclofenac sodium $75 \mathrm{mg}$ was administered as needed during the study period (maximum two times).

Side effects, such as flushing, sedation, nausea, vomiting, bradycardia, tachycardia and decrease in blood pressure $>15 \%$ of baseline values, were recorded when the VAS scores were evaluated.

\section{Statistical analysis}

Data were analyzed using SPSS version 16.0 (IBM Corporation, USA). Numerical variables were examined for normality. Patient characteristics and operative time data were analyzed using the Student's $t$ test. VAS data were analyzed using a two-way repeatedmeasures ANOVA with time and treatment as factors. A post hoc Tukey test was applied to determine significant differences between
TABLE 2

Magnesium level and postoperative consumption of morphine + bupivacaine and diclofenac

\begin{tabular}{lcc}
\hline & \multicolumn{2}{c}{ Group } \\
\cline { 2 - 3 } & Control $(\mathbf{n}=30)$ & Magnesium $(\mathbf{n}=30)$ \\
\hline Magnesium, $\mu \mathrm{M}$ & $817 \pm 78$ & $891.87 \pm 12^{*}$ \\
Morphine + bupivacaine & $58.8 \pm 17.8$ & $44.4 \pm 16.8^{* *}$ \\
$\quad$ consumption, $\mathrm{mL}$ & & $20.25 \pm 9.75^{\star *}$ \\
Diclofenac sodium, mg & $95.25 \pm 20.25$ & \\
\hline
\end{tabular}

Data presented as mean $\pm S D$. ${ }^{*} P<0.05 ;{ }^{* *} P<0.01$

the treatment and control groups. Descriptive data are expressed as mean \pm SD. Sample size was estimated using pain scores as the primary variable. A sample size of 30 patients was deemed to be sufficient to detect a difference of $1 \mathrm{~cm}$ on the VAS, as well as an SD of $1 \mathrm{~cm}$ at an alpha threshold of 0.007 with $90 \%$ power; $\mathrm{P}<0.05$ was considered to be statistically significant and was adjusted to 0.007 when multiple comparisons were performed, according to Bonferroni.

\section{RESULTS}

A total of 67 patients with an American Society of Anesthesiologists physical status class of I or II (38 men and 29 women) underwent arthroscopic shoulder surgery performed by the same surgeon. The results of seven patients (four from group M and three from group C) were not included in the study because of accidental catheter withdrawal in the postoperative period. These patients were excluded from the study after withdrawal of their catheter.

The groups were comparable with regard to age (range 23 to 58 years of age), weight range ( $56 \mathrm{~kg}$ to $98 \mathrm{~kg}$ ), sex distribution and operation time (Table 1$)$. The mean $( \pm \mathrm{SD})$ heart rates in groups $\mathrm{C}$ and $\mathrm{M}$ before induction and during the operation were $76 \pm 4.5$ beats $/ \mathrm{min}$ versus $75.1 \pm 3.5$ beats $/ \mathrm{min}$, and $74.1 \pm 2.8$ beats $/ \mathrm{min}$ versus $73.4 \pm 2.1$ beats $/ \mathrm{min}$, respectively. The average mean arterial pressure in the control and magnesium groups were $92.4 \pm 6.1 \mathrm{mmHg}$ versus $93.3 \pm 6.7 \mathrm{mmHg}$, and $93.7 \pm 2.5 \mathrm{mmHg}$ versus $94.4 \pm 3.2 \mathrm{mmHg}$, respectively. There was no significant difference in mean heart rate and arterial pressure between the two groups at any of the time points at which they were measured.

The demographic characteristics and operation times were found to be similar between the groups (Table 1). The total amount of morphine + bupivacaine used in group $M$ was significantly higher than in group C (Table 2). In addition, the total amount of diclofenac sodium needed was significantly higher in group C (Table 2). Postoperative magnesium levels were significantly higher in group $\mathrm{M}$; however, all were within the normal range $(657.6 \mu \mathrm{M}$ to $1068.6 \mu \mathrm{M})$

Pain scores measured at rest $1 \mathrm{~h}, 2 \mathrm{~h}, 6 \mathrm{~h}, 8 \mathrm{~h}$ and $12 \mathrm{~h}$ after the end of surgery were significantly lower in group $\mathrm{M}$ than in group $\mathrm{C}$ (Figure 1). Furthermore, pain scores $1 \mathrm{~h}, 2 \mathrm{~h}, 6 \mathrm{~h}, 8 \mathrm{~h}$ and $12 \mathrm{~h}$ after the end of surgery during passive motion in group $\mathrm{M}$ were significantly lower than in group C (Figure 2).

In group $\mathrm{M}$, three patients experienced nausea, two experienced vomiting and two exhibited flushing. In group C, two patients experienced nausea and vomiting. Noninvasive blood pressure measurements and heart rate did not change significantly. No patients complained of postoperative effects of sedation.

\section{DISCUSSION}

In the present study, intra-articular injections of magnesium were found to have analgesic effects after arthroscopic shoulder surgery. The treatment decreased patients' postoperative bupivacaine + morphine consumption and additional analgesic need after arthroscopic shoulder surgery until $12 \mathrm{~h}$ postoperatively with passive movement and at rest.

Arthroscopic shoulder procedures have become common in current orthopedic and anesthetic practice. Although arthroscopic shoulder surgery is less invasive and painful than open shoulder surgery, it can still cause severe postoperative pain. Efficient pain relief is needed for patients' well being, early rehabilitation and faster recovery (12). 


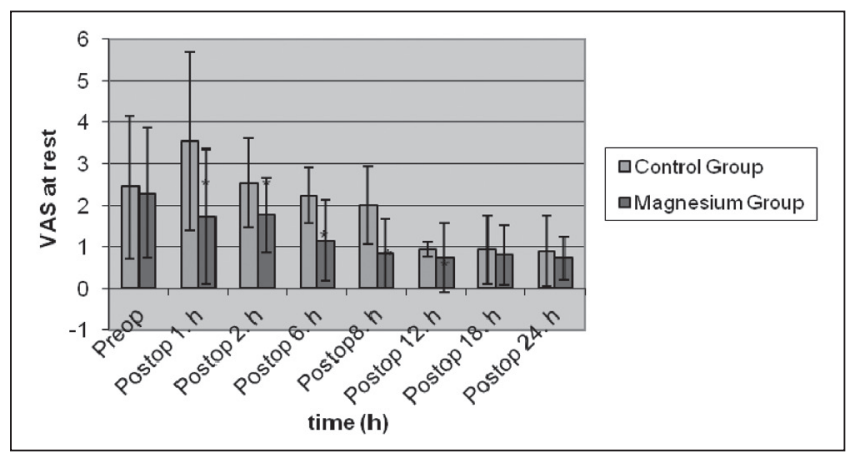

Figure 1) Visual analogue scale (VAS) scores at rest in control $(n=30)$ and magnesium $(n=30)$ groups (mean $\pm S D) .{ }^{*} P<0.05$. Preop Preoperative; Postop Postoperative

Interscalene brachial plexus blocks, wound infiltrations and intraarticular injections of various drugs are methods used to decrease postoperative pain $(12,13)$. The advantages of the intra-articular technique are its simplicity and minimal risk for complications.

The peripheral antinociceptive effect of NMDA antagonism have been precisely defined. NMDA antagonists decrease the excitability of C-fibres, which play a role in the central processing of pain (14-16).

NMDA receptors play an important role in central nociceptive transmission, modulation and sensitization of acute pain states (17). NMDA receptors are located centrally and peripherally, in the joints as well as in skin and muscles $(14,18,19)$, and play a role in sensory transmission of noxious stimuli. Magnesium ions are centrally positioned in NMDA receptors and inactivate the receptors. When an afferent stimulus is present, the resulting depolarization causes the centrally located magnesium ion to move out of the pore of the NMDA receptor, which allows calcium, sodium and potassium ions to flow through the pore (20). Magnesium can be considered to be a physiological blocker of NMDA receptors (21).

Magnesium has been reported to produce important analgesic effects, including attenuation of neuropathic pain and potentiation of morphine analgesia $(6,22)$. Turan et al $(23)$ reported that magnesium improved the overall quality of analgesia and enhanced the anesthesia provided by lidocaine for intravenous regional anesthesia.

The exact mechanism of magnesium analgesia has not been precisely defined. The median effective concentration of magnesium required to block NMDA receptors has been reported to be between $400 \mu \mathrm{M}$ and $600 \mu \mathrm{M}$ (16). However, the magnesium levels measured postoperatively in the present study were within the normal range - ie, they were higher than these levels. Although the beneficial effect of magnesium may be its antagonistic effect on NMDA receptors, its effects on calcium channels may also play a role (8). In terms of other mechanisms of action of magnesium, the ability of magnesium to block voltage-gated calcium channels is most likely to be relevant in the present study. It has been reported that calcium channel blockers have morphine-enhancing effects in the context of chronic pain (24). Elsharnouby et al (25) evaluated the analgesic properties of intraarticular magnesium and bupivacaine after arthroscopic knee surgery and concluded that the analgesia effect of magnesium may be due more to pharmacodynamics than a pharmacological receptor effect.

According to the literature, magnesium is used for postoperative pain relief intravenously, intrathecally and epidurally. Perioperative intravenous magnesium can reduce opioid consumption and pain scores in the first $24 \mathrm{~h}$ postoperatively, without any reported serious side effects (26). Magnesium can be considered to be an efficacious adjunct to postoperative analgesia (4).

The analgesic effect of intra-articular magnesium after arthroscopic knee surgery has been evaluated and confirmed in several studies $(4,27)$. Bondok and Abd El-Hady (4) reported that intra-articular administration of $500 \mathrm{mg} \mathrm{MgSO}_{4}$ at the conclusion of arthroscopic knee surgery improved postoperative pain scores. It also increased the

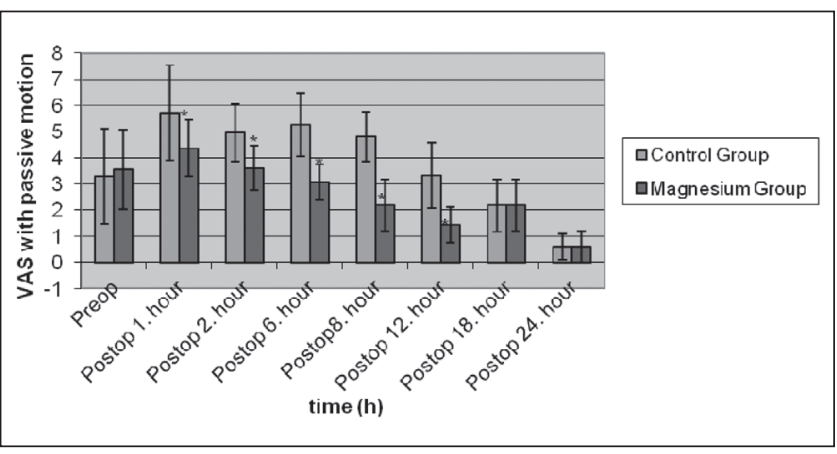

Figure 2) Visual analogue scale (VAS) scores with passive motion in control $(n=30)$ and magnesium $(n=30)$ groups $($ mean $\pm S D) . * P<0.05$. Preop Preoperative; Postop Postoperative

time to the first rescue analgesic request and decreased the need for other analgesic medications. Elsharnouby et al (25) concluded that $1000 \mathrm{mg}$ intra-articular magnesium combined with bupivacaine reduced postoperative pain compared with either bupivacaine or magnesium alone, or with a saline placebo. In addition, Koltka et al (27) reported that the intra-articular administration of $500 \mathrm{mg} \mathrm{MgSO}_{4}$, $100 \mathrm{mg}$ levobupivacaine and $8 \mathrm{mg}$ lornoxicam provided better pain relief and less analgesic requirements following outpatient arthroscopic knee surgery compared with placebos. They found that magnesium decreased postoperative pain scores compared with placebos, although this effect was not statistically significant after $4 \mathrm{~h}$ (27). In our study, however, analgesia was significantly higher until $12 \mathrm{~h}$ postoperatively; both groups were comparable thereafter. The longer duration of analgesia may be due to the higher doses of magnesium, or the presence of more NMDA receptors in shoulder joints. Kamal and Sdeek (28) evaluated the effects of intra-articular magnesium $(1000 \mathrm{mg} ; 25 \mathrm{~mL})$, bupivacaine $(0.25 \% ; 25 \mathrm{~mL})$ and magnesium + bupivacaine on postoperative analgesia after arthroscopic shoulder surgery and reported that magnesium combined with bupivacaine reduced postoperative analgesic requirements compared with either bupivacaine or magnesium alone. Thus, our results are consistent with those of other studies investigating knee surgery. All patients were discharged after $24 \mathrm{~h}$ without any complications. Serum magnesium levels were not evaluated in these studies. According to our results, serum magnesium levels increased after an intra-articular injection of $1000 \mathrm{mg}$ magnesium; however, the increased levels remained within the normal range. In a meta-analysis by Albrecth et al (26), measured magnesium levels were also higher compared with placebo groups (mean difference $0.42 \mathrm{mmol} / \mathrm{L}$ ), but they were unable to find any studies investigating doses in the literature. We could not find any data relating serum concentrations to analgesic properties of magnesium in the literature, although Koinig et al (11) reported that decreased intraoperative magnesium levels may explain the increase in analgesic requirements.

There were several limitations to the present study. First, the chondrotoxic effects of magnesium were not evaluated. Second, patients' VAS scores were evaluated for only $24 \mathrm{~h}$, and no long-term data regarding pain and analgesic requirements or complications were obtained. Although there was a risk for catheter infection, the removed catheters were not cultured. None of the patients complained about redness, swelling or discharge at the catheter site.

Although previous research investigating the use of magnesium sulphate intra-articularly reported no serious side effects, it is only licensed for intravenous administration (23). Future studies must evaluate the side effects of intra-articular injections of magnesium to ensure its safe use.

\section{CONCLUSION}

Magnesium causes a reduction in postoperative pain compared with saline when administered intra-articularly. Further studies comparing 
the effects of intravenous/intramuscular with intra-articular injections of magnesium at different doses are recommended.

ACKNOWLEDGEMENTS: TB Saritas participated in the study design, data collection, interpretation of the results and drafted the manuscript. $\mathrm{H}$ Borazan contributed to the study design, data collection and results interpretation. S Okesli provided study supervision and manuscript revision for intellectual content. M Yel contributed to study design, supervision and interpretation of the results for provided revisions. S Otelcioglu provided study supervision and manuscript revisions. All authors read and approved the final manuscript.

DISCLOSURES: The authors have no conflicts of interest to declare.

\section{REFERENCES}

1. Gentili M, Houssel P, Osman M, Henel D, Jubel A, Bonnet F Intra-articular morphine and clonidine produce comparable analgesia but the combination is not more effective. Br J Anaesth 1997;79:660-1.

2. Yang LC, Chen LM, Wang CJ, Buerkle H. Postoperative analgesia by intraarticular neostigmine in patients undergoing knee arthroscopy. Anesthesiology 1998;88:334-9.

3. Batra YK, Mahajan R, Bangalia SK, Nagi ON, Dhillon MS. Bupivacaine/ketamine is superior to intraarticular ketamine analgesia following arthroscopic knee surgery. Can J Anaesth 2005;52:8:832-6.

4. Bondok RS, Abd El-Hady AM. Intra-articular magnesium is effective for postoperative analgesia in arthroscopic knee surgery. Br J Anaesth 2006;97:389-92.

5. James MFM. Clinical use of magnesium infusions in anesthesia. Anesth Analg 1992;74:129-36.

6. Feria M, Abad F, Sanchez A, Abreu P. Magnesium sulphate injected subcutaneously suppresses autotomy in peripherally deafferented rats. Pain 1993;53:287-93.

7. Tramer MR, Schneider J, Marti R, Rifat K. Role of magnesium sulfate in postoperative analgesia. Anesthesiology 1996;84:340-7.

8. Iseri LT, French JH. Magnesium: Nature's physiologic calcium blocker. Am Heart J 1984;108:188-93.

9. Woolf CJ, Thompson SW. The induction and maintenance of central sensitization is dependent on N-methyl-D-aspartic acid receptor activation; implications for the treatment of post-injury pain hypersensitivity states. Pain 1991;44:293-9.

10. Levaux Ch, Bonhomme V, Dewandre PY, Brichant JF, Hans P. Effect of intraoperative magnesium sulphate on pain relief and patient comfort after major lumbar orthopaedic surgery. Anaesthesia 2003;68:131-5.

11. Koinig H, Wallner T, Marhofer P, Andel H, Hoerauf K, Mayer N. Magnesium sulfate reduces intra- and postoperative analgesic requirements. Anesth Analg 1998;87:206-10.

12. Borgeat A, Kalberer F, Jacob H, Ruetsch YA, Gerber C. Patient controlled interscalene analgesia with ropivacaine $0.2 \%$ versus bupivacaine $0.15 \%$ after major open shoulder surgery: The effects on hand motor function. Anesth Analg 2001;92:218-23.
13. Axelsson K, Gupta A, Johanzon E, et al. Intraarticular administration of ketorolac, morphine, and ropivacaine combined with intraarticular patient-controlled regional analgesia for pain relief after shoulder surgery: A randomized, double-blind study. Anesth Analg 2008;106:328-33.

14. Lawand NB, Willis WD, Westlund KN. Excitatory amino acid receptor involvement in peripheral nociceptive transmission in rats. Eur J Pharmacol 1997;324:169-77

15. Jackson DL, Graff CB, Richardson JD, Hargreaves KM. Glutamate participates in the peripheral modulation of thermal hyperalgesia in rats. Eur J Pharmacol 1995;284:321-5

16. Liu HT, Hollman MW, Liu W-H, Hoenemann CW, Durieux ME. Modulation of NMDA receptor function by ketamine and magnesium: Part I. Anesth Analg 2001;92:1173-81.

17. Woolf CJ. Somatic pain - pathogenesis and prevention. Br J Anaesth 1995;75:169-76.

18. Iwatsu O, Ushida T, Tani T, Lawand NB, Yamaoto H. Peripheral administration of magnesium sulfate and ketamine hydrochloride produces hypethesia to mechanical stimuli in humans. J Health Sci 2002:48:69-72.

19. Cairns BE, Svensson P, Wang K, et al. Activation of peripheral NMDA receptors contributes to human pain and rat afferent discharges evoked by injection of glutamate into the masseter muscle. J Neurophysiol 2003;90:2098-105.

20. Dickenson AH. NMDA receptor antagonists as analgesics. In: Fields HL, Liebeskind JC, eds. Progress in Pain Research and Management, Volume I. Seattle: IASP Press, 1994;173-87.

21. Fawcet WJ, Haxby EJ, Male DA. Magnesium: Physiology and pharmacology. Br J Anaesth 1999;83:302-20.

22. McCarthy RJ, Kroin JS, Tuman KJ, Penn RD, Ivankovich AD. Antinociceptive potentiation and attenuation of tolerance by intrathecal co-infusion of magnesium sulfate and morphine in rats. Anesth Analg 1998;86:830-6.

23. Turan A, Memis D, Karamanlioglu B, Guler T, Pamukcu Z. Intravenous regional anesthesia using lidocaine and magnesium. Anesth Analg 2005;100:1189-92.

24. Tramer MR, SchneiderJ, Marti RA, Rifat K. Role of magnesium sulfate in postoperative analgesia. Anesthesiology 1996;84:340-7.

25. Elsharnouby NM, Eid HE, Abou Elezz NF, Moharram AN. Intraarticular injection of magnesium sulphate and/or bupivacaine for postoperative analgesia after arthroscopic knee surgery. Anesth Analg 2008;106:1548-52.

26. Albrecht E, Kirkham KR, Liu SS, Brull R. The analgesic efficacy and safety of neuraxial magnesium sulphate: A quantitative review. Anaesthesia 2013;68:190-202.

27. Koltka K, Koknel-Talu G, Asik M, Ozyalcin S. Comparison of efficacy of intraarticular application of magnesium, levobupivacaine and lornoxicam with placebo in arthroscopic surgery. Knee Surg Sports Traumatol Arthrosc 2011;19:1884-9.

28. Kamal SM, Sdeek M. Intraarticular magnesium sulphate improves postoperative analgesia after arthroscopic shoulder surgery. AAMJ 2007;5:174-84. 


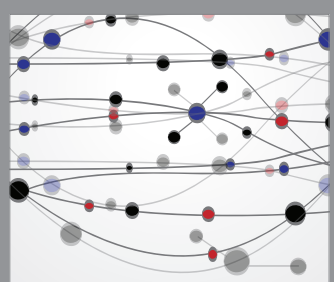

The Scientific World Journal
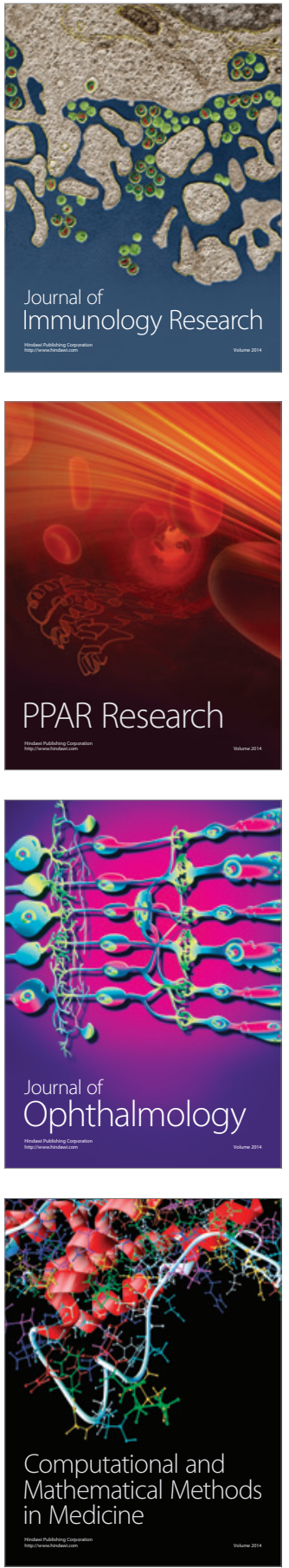

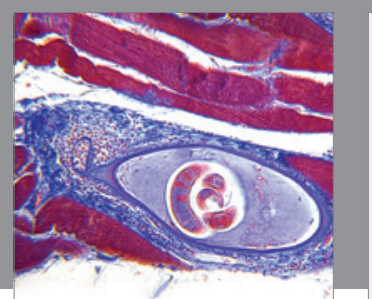

Gastroenterology Research and Practice

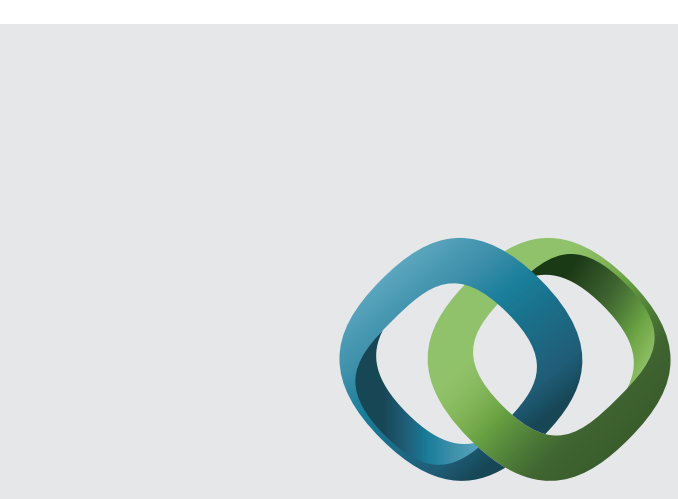

\section{Hindawi}

Submit your manuscripts at

http://www.hindawi.com
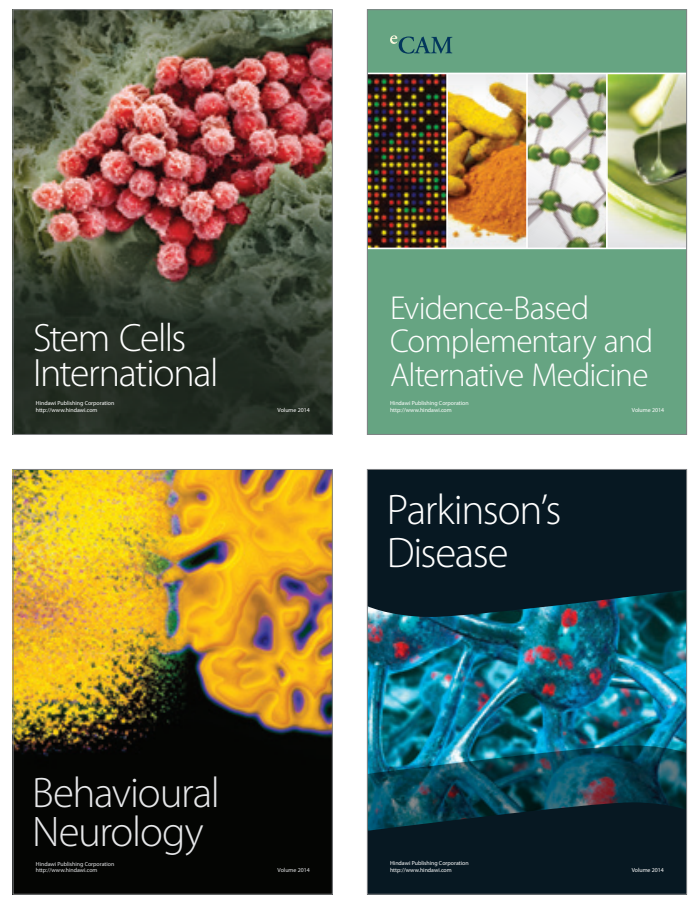
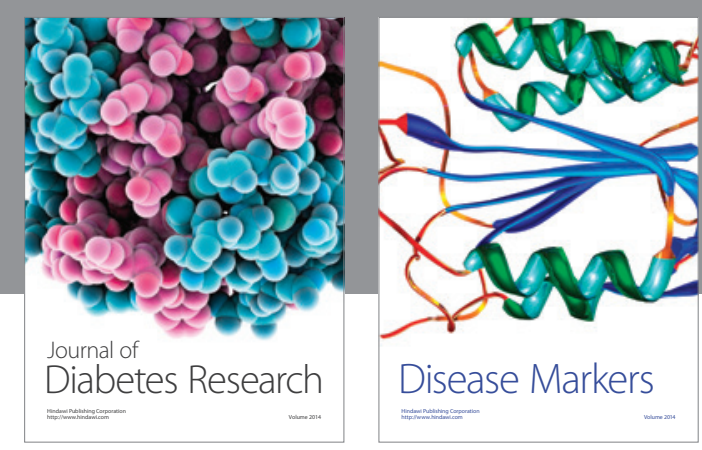

Disease Markers
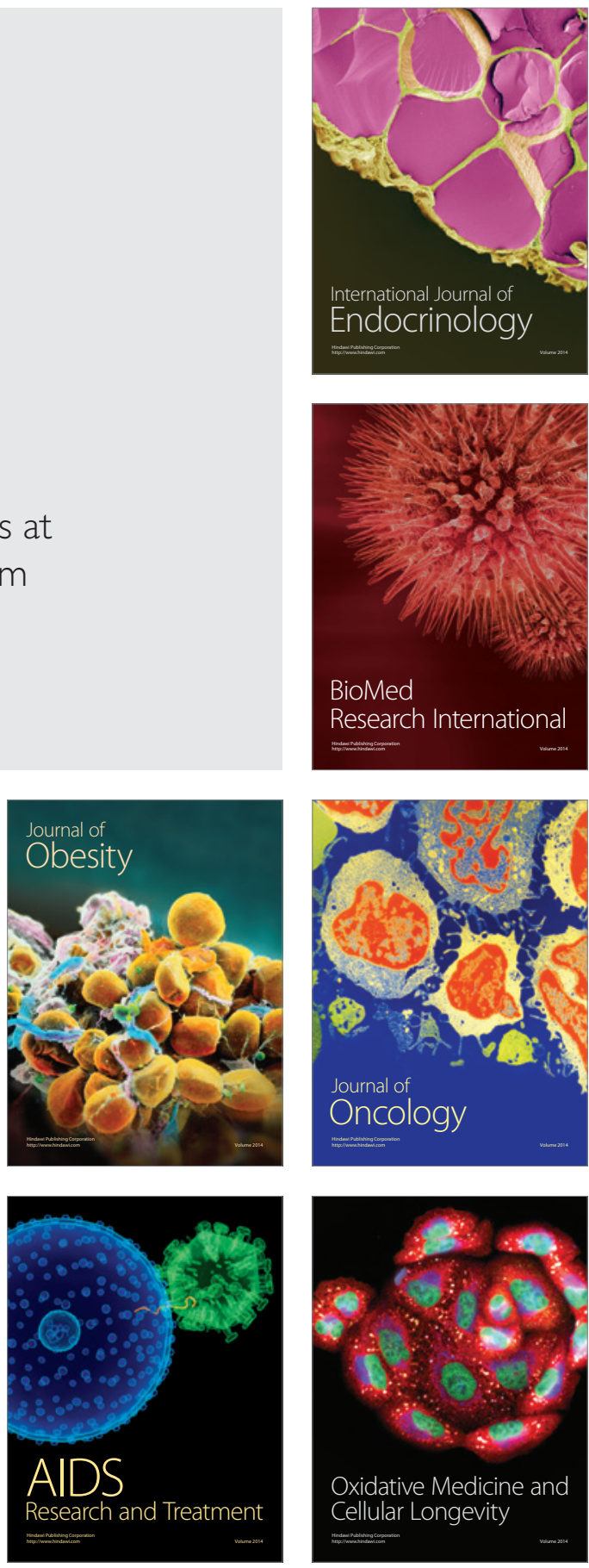